\section{PENELITIAN PENGARUH SUDUT KEMIRINGAN RAK PADA UJI CUACA LUAR TERHADAP SIFAT FISIS KETAHANAN KIKIS, BERAT JENIS SOL KARET CETAK SEPATU OLAH RAGA}

Suprapto

\section{ABSTRACT}

The aim of this research is to find out the effect of weather exposure on the physical characteristic of the abrasition and the densytas of the quali-ty of the molding rubber of the spor shoes. In this research, the samples of the experiment are installed on shelves which each of the shelve has an a $0^{\prime \prime}, 15^{\prime \prime}, 30^{\prime \prime}$, and $45^{\circ}$ angle, by directtly exposure to the out door weather The samples of the research were tested to know their physical proper-ties. It was done once in every 40 davs. Testing for the abrasition and densytas on rubber and plastic physical and in every 40 days. Testing physical tests were analysed using $T$ test. The result of the research showed that the different angles of the selves did not affect the abrasition as well as the densytas significantly

\section{INTISARI}

Penelitian ini bertujuan untuk mengetahui pengaruh cuaca luar terhadap mutu ketahanan kikis dan berat jenis sol karet cetak sepatu olah raga. Dalam melaksanakan contoh uji dipasang diatas rak yang sudut kemiringannya diatur masing-masing : $O^{\circ}, 15^{\circ}, 30^{\circ}$ dan $45^{\circ}$, dengan cuaca langsung udara terbuka. Pengambilan contoh uji yang akan diuji sifat fisiknya diambil setiap 40 hari sekali. Pengujian ketahanan kikis dan berat jenis dilakukan di diambil setiap 40 har Laboratorium Fisis dan Khemis Barang Karet Dan Plastik BBKKP Yogyakarta dengan mengacu pada $S N I$ OT Hasil Penelitian menunjukkan bahwa dengan sudut kerhadap perubahan sifat ketahanan kikis dan berat jenis sol karet cetak sepatu olah raga.

\section{PENDAHULUAN}

Sol karet cetak sepatu olah raga merupakan bagian dari sepatu, biasanya dalam penggunaannya langsung terkena baik oleh sinar matahari maupun hujan. Mutu sol karet cetak sepatu olah raga ditentukan oleh sifat-sifat fisiknya antara lain : tegangan putus, perpanjangan putus, kekuatan sobek, ketahanan kikis, berat jenis dan sifat-sifat lainnya. Apabila sol karet cetak sepatu olah raga dalam pemakaiannya terkena terus menerus baik oleh sinar matahari maupun hujan, maka akan mengalami perubahan sifat fisiknya. Untuk mengetahui perubahan sifat yang terjadi pada sol karet cetak sepatu olah raga, maka perlu diadakan penelitian tentang pengaruh cuaca luar terhadap sifat-sifat fisika sol karet cetak sepatu olah raga. Indonesia terletak disekitar katulistiwa, dengan $8^{\circ}$ lintang utara dan $12^{\circ}$ lintang selatan. Keadaan cuaca dipengaruhi oleh suhu, kelembaban udara dan angin (5).

Pengaruh cuaca terhadap barang karet diselidiki oleh beberapa ahli antara lain :

M. FALLONSBEE (3) meneyelidiki 480 macam campuran, dari kandungan karet campuran yang Fendah sampai pada kandungan karet dalam campuran sebesar $60 \%$ dari sifat fisis yang berupa tegangan putus dan perpanjangan putus.

Menurut KRALL (3), juga membandingkan kompon yang mengandung bahan riklaim, contoh uji dibandingkan setelah diperlakukan aging alam selama : tiga bulan, enam bulan, sembilan bulan dan dua belas bulan.

Menurut Van Rossen dan Tallen (3) bahwa pengaruh cuaca terhadap barang karet antara lain :

1. Penyebab retak akan semakin meluas dengan adanya serangan ozon.

2. Cahaya mempunyai peranan penting pada pembentukan cracking terutama pada bagian yang langsung terkena penyinaran akan terjadi suatu oksidasi.

3. Bahan pelunak karet memberikan pengaruh terhadap pembentukan crack pada bagian tertentu, dimana bagian yang terkena sinar matahari akan teroksidasi nampak dengan jelas bila dibandingkan dengan campuran kompon yang terkontrol, mineral karet ini menyebabkan menjadi lebih buruk sifat fisiknya.

\section{MATERI DAN METODE PENELITIAN}

A. Materi Penelitian.

1. Bahan

Bahan-bahan yang digunakan dalam penelitian ini sebanyak 147 contoh uji ketahanan kikis dan 147 contoh uji berat jenis, dari sol karet cetak sepatu olah raga yang diproses dari kompon dengan kondisi yang sama.

2. Alat-alat yang digunakan :

a. Pisau potong contoh uji ketahanan kikis, dan alat uji ketahanan kikis.

b. Jangka sorong dan penggaris.

c. Alat uji out door.

d. Alat ukur tebal (mikrometer) dengan ketelitian 0,05 mm.

e. Neraca analitis.

\section{B. Metode Penelitian}

Penelitian ini menggunakan sebanyak 147 contoh uji ketahanan kikis dan 147 contoh uji berat jenis sol karet cetak sepatu olah raga yang diambil dari satu perusahaan dengan proses pembuatan yang sama. Penelitian ini dilaksanakan dilokasi Balai Besar Penelitian Dan Pengembangan Industri Barang Kulit, Karet Dan Plastik yang terletak didaerah Yogyakarta. Kodya Yogyakarta dengan keadaan cuaca yang selalu berubah-ubah setiap bulannya, suhu minimum $21^{\circ} \mathrm{C}$ dan suku

Vol. XII No. 23 Th. 1996/1997 
maksimum $32,9^{\circ} \mathrm{C}$ dan kelembaban relatif minimum $75 \%$ dan kelembaban relatif maksimum $88 \%$. Penelitian pengaruh cuaca diudara luar yang secara langsung terkena baik oleh sinar matahari maupun hujan, contoh uji diletakkan diatas rak yang mempunyai ukuran : panjang 1,5 meter, lebar 1 meter, tebal $3 \mathrm{~mm}$ dan pada bagian bawah diberi kaki penyangga yang terbuat dari besi dengan ketinggian 1,5 meter. Alat yang dipergunakan dalam penelitian ini dapat diatur sudut kemiringannya. Pemasangan alat tersebut menghadap arah equator. Alat yang digunakan dalam penelitian ini diatur sudut kemiringan yang berbeda-beda yaitu : $0^{0}, 15^{0}, 30^{\circ}, 45^{\circ}$

Diatas rak ini diletakkan contoh uji ketahanan kikis dan contoh uji berat enis. Sudut kemiringan rak dimaksudkan untuk mengetahui pengaruh terł idap perubahan sifat-sifat fisis dari contoh uji yang akan diteliti baik berupa ketahanan kikis. maupun berat jenisnya. Sol karet cetak sepatu olah raga yang dipakai sebagai contoh uji diperoleh dari satu macam kompon yang diproses pada kondisi yang sama, sehingga didapatkan sol karet cetak sepatu olah raga yang mempunyai mutu seragam. Dalam penelitian ini alat uji udara luar ditempatkan pada lokasi yang langsung terkena baik oleh sinar matahari maupun hujan, pada permukaan bahan contoh uji yang akan diteliti. Contoh uji yang akan diteliti diperlakukan dengan alat ini selama 480 hari dengan pengambilan contoh uji dilaksanakan setiap 40 hari sekali. Selanjutnya diadakan pengujian-pengujian sifat fisisnya yang berupa ketahanan kikis dan berat jenis, yang masing-masing dengan tiga kali ulangan Data yang diperoleh dari hasil pengujian sifat-sifat fisisnya selanjutnya dianalisa dengan menggunakan metode $T$ test.

\section{Hasil Penelititan Dan Pembahasan}

Hasil pengujian sifat fisis ketahanan kikis dan berat jenis sol karet cetak sepatu olah raga. Adapun data rata-rata dari tiga kali ulangan dapat dilihat pada tabel berikut ini :
Tabel 1 : Data rata-rata hasil uji ketahanan kikis sol karet cetak sepatu olah raga dalam satuan $\left(\mathrm{mm}^{3} / \mathrm{kgm}\right)$.

\begin{tabular}{|c|c|c|c|c|c|}
\hline \multirow{2}{*}{$\begin{array}{c}\text { Variasi Waktu } \\
\text { (hari) }\end{array}$} & Tanpa Perlakuan & \multicolumn{4}{|c|}{ Dengan Perlakuan Sudut Kemiringan Rak } \\
\cline { 3 - 6 } (blangko) & $0^{\circ}$ & $15^{\circ}$ & $30^{\circ}$ & $45^{\circ}$ \\
\hline 40 & 2,2461 & 1,56 & 1,51 & 1,51 & 1,32 \\
80 & 2,2461 & 2,14 & 1,99 & 2,10 & 1,42 \\
120 & 2,2461 & 1,57 & 1,49 & 1,55 & 1,35 \\
160 & 2,2461 & 1,55 & 1,65 & 1,60 & 1,26 \\
200 & 2,2461 & 1,61 & 1,60 & 1,64 & 1,65 \\
240 & 2,2461 & 1,85 & 2,09 & 2,67 & 1,40 \\
280 & 2,2461 & 2,18 & 2,22 & 2,02 & 1,34 \\
320 & 2,2461 & 2,28 & 2,43 & 2,46 & 1,52 \\
360 & 2,2461 & 2,42 & 2,46 & 2,48 & 1,56 \\
400 & 2,2461 & 2,48 & 2,50 & 2,51 & 1,56 \\
440 & 2,2461 & 2,50 & 2,51 & 2,51 & 2,52 \\
480 & 2,2461 & 2,54 & 2,52 & 2,51 & 1,59 \\
\hline
\end{tabular}

Tabel 2 : Data rata-rata hasil uji berat jenis sol karet cetak sepatu olah raga dalam satuan $\left(\mathrm{g} / \mathrm{Cm}^{3}\right)$

\begin{tabular}{|c|c|c|c|c|c|}
\hline Variasi Waktu & Tanpa Perlakuan & \multicolumn{4}{|c|}{ Dengan Perlakuan Sudut Kemiringan Rak } \\
\cline { 3 - 6 } (hari) & (blangko) & $0^{0}$ & $15^{\circ}$ & $30^{\circ}$ & $45^{\circ}$ \\
\hline 40 & 1,321 & 1,36 & 1,31 & 1,31 & 1,32 \\
80 & 1,321 & 1,45 & 1,36 & 1,37 & 1,42 \\
120 & 1,321 & 1,46 & 1,43 & 1,34 & 1,35 \\
160 & 1,321 & 1,19 & 1,24 & 1,49 & 1,26 \\
200 & 1,321 & 1,78 & 1,58 & 1,25 & 1,65 \\
240 & 1,321 & 1,53 & 1,37 & 1,86 & 1,40 \\
280 & 1,321 & 1,47 & 2,24 & 1,36 & 1,34 \\
320 & 1,321 & 1,50 & 1,52 & 1,57 & 1,52 \\
360 & 1,321 & 1,53 & 1,57 & 1,53 & 1,56 \\
400 & 1,321 & 1,58 & 1,58 & 1,56 & 1,56 \\
440 & 1,321 & 1,59 & 1,58 & 1,61 & 2,52 \\
480 & 1,321 & 1,58 & 1,59 & 1,57 & 1,59 \\
\hline
\end{tabular}

Dengan melihat tabel pengujian diatas sifat fisis sol karet cetak sepatu olah raga, dari data perhitungan perubahan sifat fisis yang berupa ketahanan kikis dan uji berat jenis, maka contoh uji setelah dikenakan perlakuan cuaca baik sinar matahari maupun hujan selama 480 hari, dengan sudut kemiringan yang berbeda-beda, 
ternyatamenunjukkan perubahan sifat fisis yang sama antara rak yang satu dengan rak lainnya. Untuk mengetahui apakah diantara perlakuan, yang dikenakan pada contoh uji sol karet cetak sepatu olah raga yang diuji berbeda nyata atau tidak, maka dari data hasil uji sifat fisis dianalisa dengan statistik metode $\mathrm{T}$ test yang memberikan hasil sebagai berikut :

Seperti pada hasil uji ketahanan kikis dari contoh uji sol karet cetak sepatu lah raga yang dikenakan perlakuan cuaca udara luar dengan sudut kemiringan rak antara $0^{\circ}$ dan $15^{\circ}$ selama 480 hari ternyata menunjukkan perhitungan $t$ hitung $0,0380<$ dari t tabel 2,201. Jadi sifat fisis ketahanan kikis sol karet cetak sepatu olah raga pada sudut kemiringan rak antara $0^{\circ}$ dan $15^{\circ}$ perbedaan tidak nyata. Untuk sifat fisis sol karet cetak sepatu olah raga pada hasil uji berat jenis dengan sudut kemıringan rak antara $0^{\prime}$ dan $15^{\circ}$ menunjukkan perhitungan thitung - $0.380<$ dar t tabel 2.201. Jadi sifat fisis berat jenis sol karet cetak sepatu olah raga pada sudut kemiringan rak antara $0^{\circ}$ dan $15^{\prime \prime}$ perbedaan tidak nyata.

ntuk sifat fisis sol karet cetak sepatu olah raga pada hasil uji berupa ketahanan kikis dengan sudut kemiringan rak antara $0^{\circ}$ dan $30^{\circ}$ selama 480 har menunjukkan perhitungan thitung $-0,77<$ dari t tabel 2,201. Jadi sifat fisis ketahanan kikis pada sudut kemiringan rak antara $0^{\circ}$ dan $30^{\circ}$ selama 480 hari perbedaan tidak nyata.

Untuk sifat fisis sol karet cetak sepatu olah raga pada hasil uji berat jenis dengan sudut kemiringan rak antara $0^{\circ}$ dan $30^{\circ}$ selama 480 hari menunjukkan perhitungan thitung $0,3035<$ dari $t$ tabel 2,201 . Jadi sifat fisis berat jenis sol karet cetak sepatu untuk olah raga pada sudut kemiringan rak antara $0^{\circ}$ dan $30^{\circ}$ selama 480 hari perbedaan tidak nyata.

Untuk sifat fisis sol karet cetak sepatu olah raga pada hasil uji ketahanan kikis yang dikenakan perlakuan cuaca terhadap sinar matahari dan hujan pada sudut kemiringan rak antara $15^{\circ}$ dan $45^{\circ}$ selama 480 hari ternyata menunjukkan perhitungan thitung $0,03447<$ dari t tabel 2,201. Jadi sifat fisis ketahanan kikis sol sepatu karet cetak olah raga pada sudut kemiringan rak antara $15^{\circ}$ dan $45^{\circ}$ selama 480 hari perbedaan tidak nyata. Untuk sifat fisis sol karet cetak sepatu olah raga pada hasil uji berat jenis dengan sudut kemiringan rak antara $15^{\circ}$ dan $45^{\circ}$ selama 480 hari menunjukkan perhitungan $t$ hitung $-0,352<$ dari $t$ tabel 2,201 . Jadi sifat fisis berat jenis sol karet cetak sepatu olah raga pada sudut kemiringan rak antara $15^{\circ}$ dan $45^{\circ}$ selama 480 hari perbedaan tidak nyata.

Untuk sifat fisis sol karet cetak sepatu olah raga pada hasil uji ketahanan kikis yang dikenakan perlakuan cuaca terhadap sinar matahari dan hujan pada sudut kemiringan rak antara $15^{\circ}$ dan $30^{\circ}$ selama 480 hari ternyata menunjukkan perhitungan hitung $-0,928<$ dari $t$ tabel 2,201 . Jadi sifat fisis ketahanan kikis sol karet cetak sepatu olah raga pada sudut kemiringan rak antara $15^{\circ}$ dan $30^{\circ}$ selama 480 hari perbedaan tidak nyata.
Untuk sifat fisis sol karet cetak sepatu olah raga pada hasil uji berat jenis dengan sudut kemiringan rak antara $15^{\circ}$.dan $30^{\circ}$ selama 480 hari menunjukkan perhitungan $t$ hitung $0,488<$ dari t. Jadi sifat fisis yang berupa berat jenis sol karet cetak sepatu olah raga pada sudut kemiringan rak antara $15^{\circ}$ dan $30^{\circ}$ selama 480 hari perbedaan tidak nyata.Untuk sifat fisis sol karet cetak sepatu olah raga pada hasil uji ketahanan kikis yang dikenakan perlakukan terhadap cuaca sinar matahari dan hujan pada sudut kemiringan rak antara $30^{\circ}$ dan $45^{\circ}$ selama 480 hari ternyata menunjukkan perhitungan $t$ hitung $0,754<$ dari t tabel 2,201. Jadi sifat fisis ketahan kikis sol karet cetak sepatu olah raga pada sudut kemiringan rak antara $30^{\circ}$ dan $45^{\circ}$ selama 480 hari perbedaan tidak nyata.

Untuk sifat fisis sol karet cetak sepatu olah raga pada hasil uji berat jenis yang diperlukan dengan cuaca udara luar dengan sudut kemiringan rak antara $30^{\circ}$ dan $45^{\circ}$ selama 480 hari menunjukkan perhitungan $t$ hitung $-0.582<$ dari t tabel 2.201. Jadi sifat fisis sol karet cetak sepatu olah raga yang berupa berat jenis, dengan sudut kemiringan rak antara $30^{\circ}$ dan $45^{\circ}$ selama 480 hari perbedaan tidak nyata.

Untuk sifat fisis sol karet cetak sepatu olah raga pada hasil uji ketahan kikis yang dikenakan perlakukan cuaca terhadap sinar matahari dan hujan pada sudut kemiringan rak antara $45^{\circ}$ dan $0^{\circ}$ selama 480 hari ternyata menunjukkan perhitungan t hitung $1,1005<$ dari t tabel 2,201. Jadi sifat fisis ketahanan kikis sol karet cetak sepatu olah raga pada sudut kemiringan rak antara $45^{\circ}$ dan $0^{\circ}$ selama 480 hari perbedaan tidak nyata.

Untuk sifat fisis sol karet cetak sepatu olah raga pada hasil uji berat jenis dengan sudut kemiringan rak antara $45^{\circ}$ dan $0^{\circ}$ selama 480 hari menunjukkan perhitungan $t$ hitung $0,443<$ dari $t$ tabel 2,201. Jadi sifat fisis berat jenus sol karet cetak sepatu olah raga pada sudut kemiringan rak antara $45^{\circ}$ dan $0^{\circ}$ selama 480 hari perbedaan tidak nyata.

\section{KESIMPULAN}

1. Perubahan sifat fisis cuplikan setelah dikenakan perlakuan udara luar selama 480 hari, dengan sudut kemiringan rak yang berbeda-beda ternyata menunjukkan perubahan sifat yang tidak jauh berbeda antara rak yang satu dengan rak yang lainnya.

2. Dari hasil analisa statistik sifat ketahanan kikis sol sepatu karet cetak untuk olah raga, dari enam kali perlakuan tidak ada perbedaan yang nyata antara rak yang satu dengan rak lainnya.

3. Dari hasil analisa statistik sifat berat jenis sol sepatu karet cetak untuk olah raga, dari enam kali perlakuan tidak ada perbedaan yang nyata antara rak yang satu dengan rak lainnya. 


\section{DAFTAR PUSTAKA}

Polymer Aplied Science Publishere 19.

David Sinas, Weathering of Polymer Aplied Science Pude, New York 1977.

2. Gouri. K. Jhon, Wiley, Statistical Concepts and

3. Kluckous Paul Dr. Ing, Rubber and Plastic, London Cesign, Second Edition, MC.

4. Winer BJ. Statistical Prinsiples in

Grow - Hill Kegakusha, 1971.

5. Sudiran Resosudarmo Porf. Dr. MA, Ilmu Bunu Alam, PT Rosda (Rj) Jayapura. 